\title{
Kehilangan Bahan Kering, Acid Detergent Fiber dan N-Acid Detergent Fiber Daun Moringa oleifera Secara In Vitro
}

\author{
Loss of Dry Matter, Acid Detergent Fiber and N-Acid Detergent Fiber of Moringa oleifera \\ Leaves In Vitro
}

\section{F. Nisa, A. Subrata dan E. Pangestu}

Fakultas Peternakan dan Pertanian, Universitas Diponegoro, Semarang. nisafaizzatun@gmail.com

\begin{abstract}
This research was conducted at Feed and Nutrition Laboratory, Faculty of Animals and Agricultural Science, Diponegoro University, Semarang starting on October - November 2016. The aims from this research was to assessed the loss of Dry Matter, Acid Detergent Fiber and N-Acid Detergent Fiber Moringa oleifera with in vitro method. The research had been done in three stages: preparation, in vitro analysis, analysis of DM, ADF and NADF. The material used were goat rumen liquor, Moringa leaves and Leucana leucephala leaves as a comparison. The nutrient loss tested using Tilley and Terry methode in the first stage (fermentative). The Acid etergent Fiber (ADF) tested using Van Soest method. The Nitrogen-Acid Detergent Fiber (N-ADF) tested using Kjeldhal methode. The result showed that percentage loss DM of Moringa leaves was significantly higher $(\mathrm{p} \leq 0,05)$ than leucana leucephala leaves $(71.91 \%$ vs. $58.02 \%)$. The percentage loss ADF of moringa leaves was not different $(\mathrm{p} \geq 0,05)$ compared to Leucana leucephala leaves $(57,09 \%$ vs $52,53 \%)$. The percentage loss N-ADF of Moringa leaves was significantly lower $(\mathrm{p} \leq 0.05)$ compared with Leucana leucephala leaves $(24.09 \%$ vs $43.55 \%)$. The conclusion of the research was that the nitrogen quality of moringa leaves better than Leucana leucephala leaves show from the cell wall content.
\end{abstract}

Key words: fiber, cell wall nitrogen, Moringa leaves

\begin{abstract}
ABSTRAK
Penelitian ini dilaksanakan di Laboratorium Ilmu Nutrisi dan Pakan, Fakultas Peternakan dan Pertanian, Universitas Diponegoro, Semarang mulai bulan Oktober-November 2016. Penelitian ini bertujuan untuk mengkaji kehilangan Bahan Kering (BK), Acid Detergen Fiber (ADF) dan N-Acid Detergen Fiber (N-ADF) daun kelor secara in vitro. Penelitian dilakukan dalam tiga tahap yaitu persiapan, uji in vitro, analisis BK, $A D F$ dan $N-A D F$. Materi yang digunakan yaitu cairan rumen kambing PE, daun kelor dan daun lamtoro yang digunakan sebagai pembanding. Uji kehilangan nutrien dilakukan secara in vitro dengan menggunakan metode Tilley dan Terry pada tahap pertama (fermentatif). Uji Acid Detergent Fiber (ADF) dilakukan menurut metode Van Soest. Uji Nitrogen-Acid Detergen Fiber (N-ADF) dilakukan menurut metode Kjeldhal. Hasil penelitian menunjukan bahwa persentase kehilangan BK daun kelor berbeda nyata lebih tinggi $(\mathrm{p} \leq 0,05)$ dibandingkan dengan daun lamtoro $(71,91 \%$ vs $58,02 \%)$. Persentase kehilangan ADF daun kelor tidak berbeda nyata $(p \geq 0,05)$ dibandingkan dengan daun lamtoro $(57,09 \%$ vs $52,53 \%)$. Persentase kehilangan N-ADF daun kelor berbeda nyata lebih rendah $(\mathrm{p} \leq 0,05)$ dibandingkan dengan daun lamtoro $(24,09 \%$ vs $43,55 \%)$. Kesimpulan dari hasil penelitian adalah daun kelor memiliki kualitas nitrogen yang lebih baik dibandingkan dengan daun lamtoro dilihat dari kandungan $\mathrm{N}$ dinding sel yang lebih rendah.
\end{abstract}

Kata kunci: serat, nitrogen dinding sel, daun kelor

\section{PENDAHULUAN}

Komponen yang sangat berpengaruh pada usaha peternakan berasal dari biaya pakan. Biaya pakan dalam usaha ternak ruminansia dapat mencapai 40 hingga 60 persen dari total pengeluaran. Pemenuhan kebutuhan pakan pada ternak ruminansia sering menjadi factor pembatas, hal tersebut disebabkan terbatasnya lahan tanaman pakan, maka dari itu diperlukan pakan alternatif agar dapat menjadi solusi pemenuhan kebutuhan pakan. 
Moringa oleifera atau disebut juga dengan tanaman kelor merupakan tanaman pohon sejenis legum yang dapat digunakan sebagai pakan ternak. Tanaman kelor mengandung banyak nutrien yang baik untuk ternak yang meliputi protein kasar 30,29\%, lemak kasar 6,5\%, kadar abu 7,64\%, neutral detergent fiber $11,4 \%$, acid detergent fiber $8,49 \%$, acid detergent lignin 1,8\%, hemicellulose $2,91 \%$, cellulose $4,01 \%$, tanin $3,12 \mathrm{mg} / \mathrm{g}$ dan total polifenol 2,02\% (Moyo et al., 2011). Penggunaan tanaman kelor sebagai pakan masih belum populer karena terbatasnya informasi.

Kualitas protein pada pakan dapat dilihat dari banyaknya protein yang dapat dicerna oleh ternak. Semakin tinggi protein dalam pakan yang dapat dicerna oleh ternak maka kualitas protein pada pakan tersebut semakin baik. Protein tersusun atas protein murni dan NPN (Non Protein Nitrogen).

Uji mutu protein pakan hijauan dapat dilakukan dengan menentukan jumlah protein yang tidak tersedia yaitu yang terikat oleh dinding sel. Sesuai sistem ekstraksi serat menurut Van Soest (1984), fraksi protein dibagi atas beberapa fraksi yaitu NPN (Non Protein Nitrogen) dan protein murni yang terbagi menjadi protein murni yang terdegradasi dengan laju cepat, protein murni dengan laju degradasi sedang, protein dengan laju degradasi lambat atau yang terikat oleh dinding sel dan nitrogen yang tidak dapat didegradasi. Nitrogen pada tanaman pakan terkandung pada fraksi neutral detergent soluble (NDS) dan neutral detergent fiber (NDF). Neutral detergent fiber mengandung

acid detergent fiber (ADF) didalamnya terdapat nitrogen yang terikat pada ADF membentuk lignified nitrogen atau nitrogen yang terikat oleh lignin. Senyawa N yang terikat oleh lignin disebut dengan N-ADF akan menyulitkan mikrobia rumen untuk mendegradasi, sehingga jumlah $\mathrm{N}$ di dalam rumen menjadi terbatas. Hal tersebut dapat menurunkan kemampuan mikroba rumen. Protein tanaman kelor yang tinggi perlu dikaji kemampuannya dalam menyediakan $\mathrm{N}$ bagi mikroba rumen.

Penelitian ini bertujuan untuk mengevaluasi kulitas $\mathrm{N}$, degradabilitas bahan kering, degradabilitas ADF tanaman kelor secara in vitro. Manfaat dari penelitian ini adalah memberikan informasi pemanfaatan tanaman kelor sebagai pakan alternatif untuk ternak ruminansia.

\section{MATERI DAN METODE}

Materi yang digunakan dalam penelitian ini adalah daun kelor, daun lamtoro dan cairan rumen dari kambing Jawarandu betina berfistula berumur 12-18 bulan dengan bobot badan $31,25 \mathrm{~kg}$. Formulasi ransum untuk kambing berfistula tersaji pada Tabel 1 .

Uji kehilangan nutrien dilakukan secara in vitro dengan menggunakan metode Tilley dan Terry (1963) pada tahap pertama (fermentatif). Uji bahan kering dihitung dengan rumus:

$\%$ Kehilangan BK $=\underline{((a-(b-c))} \times 100 \%$

a

Tabel 1. Komposisi pakan kambing berfistula

\begin{tabular}{lccccc}
\hline Bahan Pakan & Formula & PK bahan & PK pakan & $\begin{array}{c}\text { TDN } \\
\text { bahan }\end{array}$ & $\begin{array}{c}\text { TDN } \\
\text { pakan }\end{array}$ \\
\hline Gaplek & 1,1 & 5,33 & 0,06 & 74,58 & 0,82 \\
Tetes & 1,0 & 0,66 & 0,01 & 75,01 & 0,75 \\
Bungkil kedelai & 17,0 & 35,97 & 6,11 & 81,10 & 13,79 \\
Bekatul & 10,7 & 9,70 & 1,04 & 67,48 & 7,22 \\
Mineral & 0,2 & 0,00 & 0,00 & 0,00 & 0,00 \\
Rumput gajah & 70,0 & 7,02 & 4,91 & 54,85 & 38,39 \\
\hline Jumlah & 100 & \multicolumn{5}{c}{12,13} & 60,97 \\
\hline
\end{tabular}

Keterangan: $a=$ Bobot BK Sampel, $b=$ Bobot BK Residu, $c=$ Bobot BK Blanko 
Uji Acid Detergent Fiber (ADF) dilakukan menurut metode Van Soest et al. (1991). Uji kehilangan $\mathrm{ADF}$ dihitung dengan rumus:

$\%$ Kehilangan $\mathrm{ADF}=\underline{\mathrm{a}-\mathrm{b}} \times 100 \%$

a

Keterangan:

$$
\begin{aligned}
& a=\text { Bobot ADF Sampel } \\
& b=\text { Bobot Residu ADF }
\end{aligned}
$$

Uji Nitrogen-Acid Detergen Fiber (N-ADF) dilakukan menurut metode Kjeldhal (1983). Uji kehilangan ADF dihitung dengan rumus:

$\%$ Kehilangan NADF $=\frac{a-b}{a} \times 100 \%$

Keterangan:

$$
\begin{aligned}
& a=\text { Bobot N ADF Sampel } \\
& b=\text { Bobot Residu N ADF }
\end{aligned}
$$

Teknik pengolahan dan analisis data menggunakan uji statistik paired T-Test dengan menggunakan program komputer SPSS versi 16.0, dengan syarat data berdistribusi normal. Normalitas data diuji menggunakan uji one sample KolmogorovSmirnov test.

\section{HASIL DAN PEMBAHASAN}

Berdasarkan hasil penelitian mengenai persentase kehilangan bahan kering, acid detergen fiber dan $\mathrm{N}$-acid detergen fiber (N-ADF) dapat dilihat pada

\begin{tabular}{|c|c|c|c|}
\hline \multirow{2}{*}{$\begin{array}{l}\text { Bahan } \\
\text { Pakan }\end{array}$} & \multicolumn{3}{|c|}{ Persentase Kehilangan } \\
\hline & $\mathrm{BK}$ & $\mathrm{ADF}$ & NADF \\
\hline & \multicolumn{3}{|c|}{--------\%------- } \\
\hline Kelor & $71,91^{\mathrm{a}}$ & 57,09 & $24,09^{\mathrm{b}}$ \\
\hline Lamtoro & $58,02^{\mathrm{b}}$ & 52,53 & $43,55^{\mathrm{a}}$ \\
\hline \multicolumn{4}{|c|}{$\begin{array}{l}\text { Keterangan : Superskrip a,b yang berbeda pada kolo } \\
\text { yang sama menunjukkan perbedaan nyata }(\mathrm{P} \leq 0,05) \text {. }\end{array}$} \\
\hline \multicolumn{4}{|c|}{$\begin{array}{l}\text { Persentase kehilangan bahan kering } \\
\text { secara in vitro }\end{array}$} \\
\hline & hilangan & bahan & tering \\
\hline & & & \\
\hline
\end{tabular}
Tabel 2.

Tabel 2. Persentase kehilangan BK, ADF dan $\mathrm{N}-\mathrm{ADF}$ dibandingkan dengan tanaman lamtoro (Tabel 2). Tingginya persentase kehilangan bahan kering pada daun kelor dapat terjadi karena kandungan serat kasar yang lebih rendah dibandingkan kandungan serat kasar daun lamtoro sehingga daun kelor lebih mudah tercerna. Daun kelor kandungan seratnya mencapai $30,53 \%$ sedangkan daun lamtoro lebih tinggi yaitu kandungannya mencapai 33,48\%. Zulkarnain et al. (2014) menyatakan bahwa hijauan pakan mempunyai keterbatasan pada kandungan serat, selulosa dan hemiselulosa yang berikatan dengan lignin sehingga kecernaannya menjadi rendah. Kandungan hemiselulosa juga mempengaruhi tingginya persentase kehilangan bahan kering karena hemiselulosa merupakan komponen serat yang lebih mudah dicerna dari pada selulosa dan lignin. Kandungan hemiselulosa daun kelor mencapai $7,37 \%$ sedangkan daun lamtoro lebih rendah yaitu $4,81 \%$. Van Shoest (1984) menyatakan bahwa hemiselulosa memiliki kemampuan untuk delignifikasi dengan berikatan dengan polisakarida sehingga lebih mudah larut/dicerna dibandingkan dengan selulosa. Persentase kehilangan bahan kering dapat tinggi apabila kandungan nitrogen yang dapat larut/dicerna tinggi. Daun kelor memiliki kandungan $\mathrm{N}$ terlarut mencapai $85,91 \%$ sedangkan daun lamtoro rendah yaitu $66,44 \%$. Semakin banyak nitrogen yang dapat dicerna maka semakin tinggi persentase kehilangan bahan kering sehingga semakin banyak nitrogen yang berikatan dengan dinding sel akan semakin rendah persentase kehilangan bahan kering. Krishnamoorthy et al. (1982) menyatakan bahwa nitrogen yang menempel pada komponen dinding sel akan lebih terproteksi dari degradasi enzimatis.

\section{Persentase kehilangan acid detergent fiber secara in vitro}

Degradabilitas ADF daun kelor tidak berbeda nyata $(\mathrm{P} \leq 0,05)$ dibandingkan degradabilitas ADF daun lamtoro sesuai Tabel 3. 
Persentase kehilangan ADF daun kelor dan daun lamtoro tidak berbeda nyata, Persentase kehilangan acid detergent fiber daun kelor yaitu $57,09 \%$ sedangkan daun lamtoro yaitu 52,53\% (Tabel 2). Hal itu dapat terjadi diduga karena daun kelor dan daun lamtoro memiliki kandungan komponen ADF yaitu selulosa dan lignin yang hampir sama. Aye dan Adegun (2013) menyatakan bahwa daun kelor dan daun lamtoro memiliki kandungan selulosa dan lignin yang hampir sama, kandungan selulosa daun kelor 2,85\% sedangkan daun lamtoro 3,62\% dan kandungan lignin daun kelor $3,92 \%$ daun lamtoro $4,77 \%$.

Kandungan ADF dapat mempengaruhi persentase kehilangan ADF. Kandungan ADF pada daun kelor yaitu $15,37 \%$ sedangkan pada daun lamtoro yaitu $23,38 \%$. Semakin tinggi kandungan selulosa dan lignin yang merupakan komponen penyusun ADF maka akan semakin sulit pula untuk dicerna. Van Soest (1984) menyatakan bahwa kecernaan dipengaruhi oleh ketersediaan selulosa yang terlignifikasi. Lignin dan komponen serat lainnya pada dinding sel seperti selulosa akan saling menempel karena bentuk komponennya yang berbentuk matriks saling berikatan sehingga sulit untuk lepas dan menghambat daya cerna. $\mathrm{Yu}$ et al. (2017) menyatakan bahwa lignin merupakan suatu polimer yang berikatan dengan phenylpropane sehingga sulit untuk diurai, lignin bekerja dengan cara menempel pada hemiselulosa dan selulosa dalam dinding sel.

\section{Persentase Kehilangan N-Acid Detergent Fiber}

Persentase Kehilangan N-ADF daun kelor nyata lebih rendah dibandingkan dengan N-ADF daun lamtoro. Persentase Kehilangan nitrogen acid detergen fiber daun kelor adalah $24,09 \%$ sedangkan daun lamtoro lebih tinggi yaitu 43,55\% (Tabel 2.). Kehilangan N-ADF daun lamtoro yang lebih tinggi menunjukan bahwa kualitas protein dinding sel daun lamtoro lebih baik dibandingkan dengan daun kelor karena lebih mudah dicerna.
Tabel 3. Persentase kandungan $\mathrm{N}$ terlarut dan $\mathrm{N}-\mathrm{ADF} /$ tidak larut

\begin{tabular}{lcc}
\hline $\begin{array}{l}\text { Bahan } \\
\text { Pakan }\end{array}$ & N terlarut & $\begin{array}{c}\text { N ADF/ tidak } \\
\text { larut }\end{array}$ \\
\hline Kelor & $----------\%$---------- \\
Lamtoro & 65,91 & 14,09 \\
\hline
\end{tabular}

Kandungan $\mathrm{N}-\mathrm{ADF}$ atau $\mathrm{N}$ dinding sel daun kelor adalah 14,09\% sedangkan daun lamtoro lebih tinggi yaitu $33,56 \%$ (Tabel 2.) sehingga dapat diketahui kandungan $\mathrm{N}$ isi sel/ $\mathrm{N}$ terlarut daun kelor lebih tinggi dibandingkan dengan daun lamtoro sehingga dapat menunjukan bahwa kualitas $\mathrm{N}$ terlarut daun kelor lebih baik dibandingkan dengan daun lamtoro. Kandungan N yang dapat larut/dicerna juga dapat menentukan tinggi rendahnya kehilangan $\mathrm{N}-\mathrm{ADF}$, semakin tinggi kandungan $\mathrm{N}$ yang larut/ dicerna maka kandungan N-ADF nya semakin rendah. Daun kelor memiliki kandungan $\mathrm{N}$ terlarut mencapai $85,91 \%$ sedangkan daun lamtoro rendah yaitu $66,44 \%$ (Tabel 3.). Semakin tinggi kandungan nitrogen yang mudah dicerna maka akan semakin rendah persentase kehilangan N-ADF karena kandungan N-ADF yang lebih rendah. Balabanli et al. (2010) menyatakan bahwa semakin tinggi kandungan nitrogen yang tersedia maka dapat menurunkan kandungan selulosa maupun lignin. Degradasi N-ADF yang rendah pada tanaman kelor dibandingkan dengan lamtoro dapat terjadi karena kandungan selulosanya yang lebih rendah, sehingga nitrogen lebih banyak terikat di lignin yang menyebabkan lebih sulit untuk dicerna. Aye dan Adegun (2013) menyatakan bahwa pada daun lamtoro selulosa yang terkandung mencapai $3,63 \%$ sedangkan selulosa daun kelor adalah $2,85 \%$.

\section{KESIMPULAN}

Kualitas nitrogen daun kelor lebih baik dibandingkan daun lamtoro dilihat dari $\mathrm{N}$ dinding sel daun kelor yang lebih rendah. 


\section{DAFTAR PUSTAKA}

Aye P. A and M. K. Adegun. 2013. Chemical composition and some functional properties of moringa, leucaena and gliricidia leaf meals. Agriculture and Biology Journal of North America. 4 (1): 71-77.

Balabanli, C., S. Albayrak and O. Yüksel. 2010. Effects of nitrogen, phosphorus and potassium fertilization on the quality and yield of native rangeland. Turkish Journal of Field Crops. 15(2): 164-168.

Krishnamoorthy, U., Muscato, T.V., Sniffen, C.J. and Van Soest, P.J., 1982. Nitrogen fractions in selected feedstuffs. J. Dairy Sci. 65: 217-255.

Moyo. B., P. J. Masika., A. Hugo and V. Muchenje. 2011. Nutritional characterization of Moringa (Moringa oleifera Lam.) leaves. African Journal of Biotechnology. 10(60): 1292512933.

Van Soest, P. J. and L. H. P. Jones. 1968. Analysis and classification of dietary fiber. Page 351 in Trace ele- ment analytical chemistry in medicine and biology. P. Bratter and P. Schramel, ed. Walter de Gruyter \& Co., New York, NY.

Van Soest, P. J. 1984. Nutritional Ecology of the Ruminant: Second Edition. Cornell University. New York.

Van Soest, P. J., J. B. Robertson, and B. A. Lewis. 1991. Methods for dietary fiber, neutral detergent fiber, and nonstarch polysaccharides in relation to animal nutrition. Journal of dairy science, 74 (10): 3583-3597.

Yu J., N. Paterson., J. Blamey, and M. Millan. 2017. Cellulose, xylan and lignin interactions during pyrolysis of lignocellulosic biomass. Journal of The science and technology of fuel and energy. Vol 191: 140-149.

Zulkarnain. D. R., Ismartoyo dan Harfiah. 2014. Karakteristik degradasi tiga jenis pakan yang disuplementasi daun gamal (Gliricidia maculata) dalam rumen kambing secara in sacco. Jurnal Ilmu Ternak dan Pakan. 3 (3): 148-153. 